\title{
ファジィ・ニューラルネットワークを利用した 未知環境に対するハイブリッド制御
}

\author{
非会員木口量夫（新潟工短大） \\ 正員福田敏男 (名古屋大)
}

\author{
Hybrid Control for an Unknown Environment Using Fuzzy Neural Network \\ Kazuo Kiguchi, Non-Member (Niigata College of Technology) \\ Toshio Fukuda, Member (Nagoya University)
}

\begin{abstract}
Robot manipulators are expected to perform sophisticated tasks in many fields. In order to perform sophisticated tasks, robot manipulators have to control both position and force simultaneously. Robots are also expected to work not only in limited environments, but also in unknown environments. However, conventional controllers have some problems to control force on unknown environments, because they do not have ability of adapting to the unknown environment. Furthermore, friction compensation is difficult, especially for an unknown environment, because the friction between the robot manipulator and the environment varies when the applied force to the environment changes. In this paper, neural networks and fuzzy-neural networks are applied to position/ force hybrid control in order to solve these problems.

The effectiveness of the proposed controller is verified with a 3DOF planar robot manipulator by computer simulations.
\end{abstract}

キーワード：ファジィ・ニューラルネットワーク、ロボットマニピュレータ，位置／力制御

\section{1.はじめに}

現在我々の身近なところで活踓しているロボットとして， 工場等で稼働している産業用ロボットが挙げられる。しか し，一般に普及している産業用ロボットは単に位置だけを 制御するものであり，単に物の位置決め等に利用されてい るものがほとんどである。近年, ロボットマニピュレータに 対し，産業用ロボットよりも高度な作業が求められている。 ロボットマニピュレータにより高度な作業, 例えば研磨作 業, 拭き取り作業作業等を実現させるためには，位置と力の 雨方を同時に制御する必要がある。また，今後のロボットは 予め設定した環境内で稼㗢するだけでなく，未知環境下で も作業できるような柔軟性も期待されている。

位置と力を同時に制御する方法として，主にハイプリッ

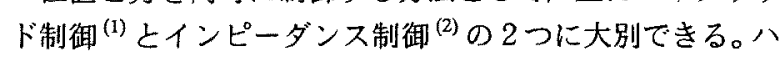
イブリッド制御では, 環境表面に対し直角な万向に力制御, その力制御の方向に対し直角方向に位置制御することによ り，位置と力を同時に直接的に制御するのに対し，インピー ダンス制御では速度と加速度も含めた位置と力の関係を制 御するというところが主な違いである。力制御においては, 環境の動特性がシステムの安定性に影響を及活すため，従
来の制御系では環境の動特性に応じてゲインを設定してや る必要があり, 動特性の未知な環境に対しては対応が難し い。そのため，力制御の研究自体は既に多くの研究例が発表 されているが，力を加える環境の特性が末知なものについ ての研究例は少なかった。また，環境に力を加えながら位固 を制御する場合, 環境とロボット間の摩擦力は, 環境に対し 加える力の大きさにより変化するため, 環境と口ボット間 の摩擦の補償が大きな問題となる。特に摩擦係数の未知な 環境では適切な摩擦補償を行うことは困難である。この問 題を避けるためにロボットのエンド・エフェクタ先端に ローラーを付けて実験した研究例 ${ }^{(3)(4)}$ はあるが，環境に力 を加えながら位置を制御する場合に有効な摩擦補償方法を 提案している研究例は見あたらない。そこで本論文では，上 記の問題に対応し，未知環境に対し位置と力のハイブリッ ド制御を行うため, ニューラルネットワーク及びファジィ・ ニューラルネットワークを応用する方法を提案する。

近年, 暧昧な情報の扱いができ, 簃密な数学モデルを使う ことなく制御できるファジィ制御 ${ }^{(5)}$ （7) や経験から学習で きる能力を持つニューラルネットワークは, ロボット制御 の分野で積極的に取り入れられてきた ${ }^{(8) \sim(11)}$ 。二ューラル ネットワークを利用して未知環境に対し適応できるハイブ 
リッド制御法を提案した例(11) もあるが，適応型のニューラ ルネットワーク制御器でさえも眼時に適応できるわけでは なく，適応するまでの間オーバーシューティング等の危険 性があった。筆者らはこの問題を解決するため，予めファ ジィ制御の方法を用いてオーバーシュートしない上うな制 御器を設計し，それをニューラルネットワークでモデル化 し，バックプロパゲーション法で学習させる、ファジィ・

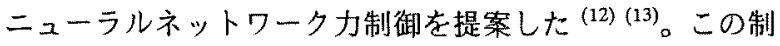
御器では, 環境の動特性が設計時に予測したものよりも柔 らかいか少し硬めの場合は特に問題なく力制御できるので, 予め硬い環境を想定しておけばほとんどの場合問題ない。 しかし，もし環境が想定したものよりかなり硬かった場合 は，やはり大きなオーバーシューティングが発生する等の 問題が生じるので，環境の動特性が設計時に用いたモデル よりも硬かった場合は, 制䅉器への入力值をオフラインで 学習したニューラルネットワーク (Input Adjusting Neural Network)により調整することでメンバーシップ関数の定義 を眼時に変更する方法を提案する。

また，環境に力を加えながらの位置制御では，摩擦補償用 ニューロンと軌道制御用ファジィ・ニューラルネットワー クを用い，状況により学習を切り替えるこよで末知環境に 対する位置制御の際の摩擦補償を実現した。

本制御法の有効性の確認は, 図 1 に示すような平面 3 自 由度ロボットマニピュレータモデルを用い，コンピュータ によるシミュレーションで行った。

\section{2. 位正/カのハイブリッド制御}

図1に示すようなロボットマニピュレータで，環境に対 し加える力とエンドエフェクタの位置及びその角度を同時 に制御するためハイブリッド制御を適用するものとする。 ハイブリッド制御は Raibert とCraigにより提案されたもの (1) で，作業空間を力制御方向之位置制御方向に分け，位置 亡力を同時に直接的に制御する方法である。この制御法を 平面ロボットマニピュレータに適用するため, まず平面口 ボットの運動方程式を考えると次式のようになる。

$$
M(q) \ddot{q}+h(q, \dot{q})+F_{c} \operatorname{sgn}(\dot{q})=\tau-J^{T} f
$$

ただし， $M(q)$ は慣性行列， $h(q, \dot{q})$ は遠心力・コリ才リ力等

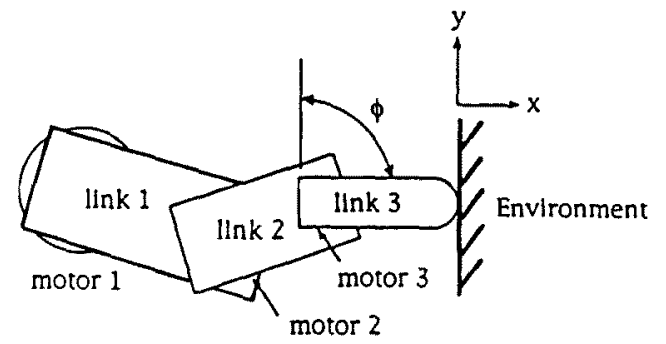

図 1 平面 3 自由度口ボットマニピュレータ

Fig.1 3DOF planar robot manipulator
の非線形項， $F$ 。関節でのクーロン摩擦ては駆動トルク ベタトル，Jはヤコビ行列,そして $f$ は環境からロボットの エンドエフェクタ先端に作用している力であり，qは関節位 置ベクトルである。

式 (1)より，必要なモータトルクは次式のように表され る。

$$
\tau=M(q) \ddot{q}+h(q, \dot{q})+F_{c} \operatorname{sgn}(\dot{q})+J^{T} f
$$

基準座標系でのエンドエフェタターの加速度と関節位置 との関係は，

$$
\ddot{x}=J \ddot{q}+\dot{J} \dot{q}
$$

で表せれる。ただし，xは基集座標系での位置ベクトルであ る。

式 (2)，(3) と位置制御方向と力制御方向を選択するセレ クションマトリクスSを使うと,

$$
\begin{aligned}
\tau= & M(q) J^{-1}\left[(I-S) u_{p}-\dot{J} \dot{q}\right]+h(q, \dot{q}) \\
& +F_{c} \operatorname{sgn}(\dot{q})+J^{T} f+J^{T} S u_{f}
\end{aligned}
$$

が得られる。ただし $u_{p}$ は位置制梅のコマンドベクトルで， Uf は力制御のコマンドベクトルである。本稿では，教は力 制御器からの出力, $u_{p}$ は位置制御器からの出力であるが, 位 置制御のうちエンドエフェクタの角度制御には特に適応能 力は必要亡されないので, 従来の加速度分解制御を用いる ことにした。このエンドェフェクタ角度制御の入力コマン ド $u_{p e}$ は次式で表される。

$$
u_{p e}=\ddot{x}_{d}+K_{v}\left(\dot{x}_{d}-\dot{x}\right)+K_{p}\left(x_{d}-x\right)
$$

ハイブリッド制御系のブロック線図を図 2 に示す。この 制御器を使うことにより, 環境に加える力とエンドエフェ クタの角度と位置が同時に制御される。

従来の制御則を利用したハイブリッド制御器により目標 の位置上力を得ることは，次の理由により困難である。第 1に、ロボットマニピュレータと環境の完璧な数学モデル を作ることは非常に難しい。第 2 に，環境の動特性がシス テムの安定性に影響するため, 未知環境での力制御に高ゲ インを使うことはできない。第 3 に、ロボットの関節内の 摩擦や，未知環境とロボット間の摩擦を完全に補償するこ

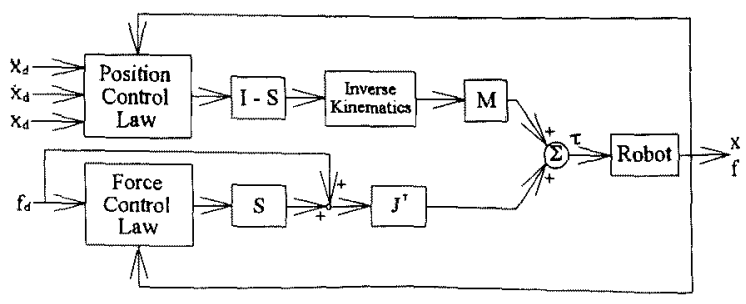

図2 ハイブリッド制御のブロック線図 Fig.2 Block diagram of hybrid control 


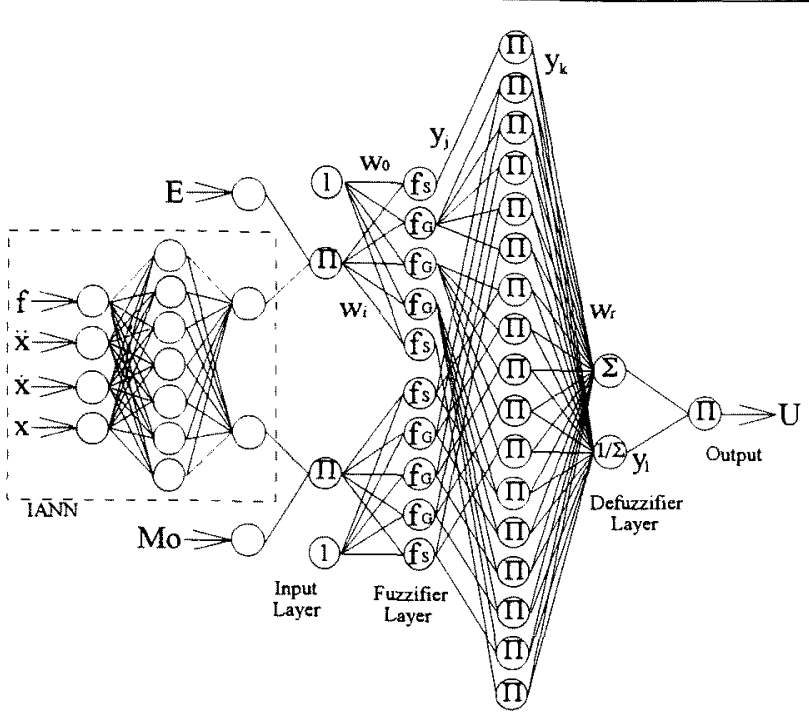

図 3 ファジィ・ニューラルネットワーク力制御器

Fig.3 Fuzzy Neural Network for force control

とは難しい。特に環境に加える力が変化する場合は，環境と ロボット間の摩擦力も変化する(この場合, ロボットの関節 内の摩擦力も変化する)。第 4 に，外乱を完全に無くするこ とはできない。さらに，環境がゴム，プラスチック，或いは 材木などの場合，温度や湿度などにより特性か時間と共に 変化するため，適応能力の無い制御則を使用するのは適切 でない。そこで、ハイブリッド制御内の位置制御と力制御の 両方に適応能力を持たせるため、ニューラルネットワーク とファジィ・ニューラルネットワークを応用する方法を次 の3，4章で説明する。

\section{3. 未知㜊靚での力制御}

動特性が末知な環境に対し，目標通りの力を加えるには， 適応型ニューラルネットワーク等を用いて制御器自身に環 境への適応能力を与えることが必要である。そこで，適応型 ニューラルネットワークを利用して未知環境に力制御を行 う方法を検討してきた ${ }^{(11)}$ 。しかしながら，適応型の二ュー ラルネットワーク制御器でさえも瞬時に未知環境に適応で きるわけではなく，適応するまでの間オーバーシューティ ング等の危険性があった。そこで筆者らは，予めファジィ制 御の方法を用いてオーバーシュートしないような制御器を 設計し，それをニューラルネットワークでモテル化し、バッ クプロパゲーション法で学習させる.ファジィ・ニューラル ネットワーク力制御を提案してきた (12) (13)。以降，ファ ジィ・ニューラルネットワーク力制御器をF N N力制御器 と呼ぶことにする。本稿では更に新しい手法として, 環境の 動特性に応じF N N力制御器への入力值を調整するニュー ラルネットワーク (Input Adjusting Neural Network) をオフ ラインで学習させ, F N N力制御器に組み込んだ。以降, こ のニューラルネットワークをI A N N と略す。本稿で提案

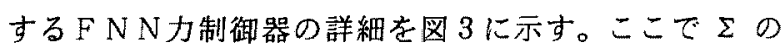

ニューロンは入力の和を出力し，ாのニューロンは入力の 積を出力するものである。

〈3・1〉F N Nカ制御器通常ロボットマニピュレー タのファジィ制御では，入力情報として誤差量とその変化 量が考えられるが, 力制御では通常湘定值にノイズが多く 含まれているため證差の変化量を利用することが難しい。 そこで誤差の変化量の代わりにマニピュレータが環境を押 す速度を利用することが考えられるが，マニピュレータが 環境を押す速度が早いか遅いかの概念はマニピュレータの 形態により異なる。つまりその形態での力制御方向の慣性 行列の大きさにより速度の概念が変わることになる。そこ でマニピュレータの速度ではなく力制御方向のマニピュ レータ運動量を入力情報として利用する。

$$
M_{o}=M_{x}(q) v
$$

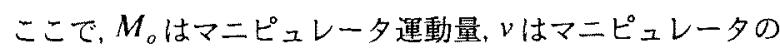
速度, $M_{x}(q)$ はマニピュレータの関節角度が $q$ のきの基準 座標系での慣性行列であり，次式のように表される。

$$
M_{x}(q)=J^{-T}(q) M(q) J^{-1}(q)
$$

前件部のファジィ変数は 5 種類 (P B , P S , Z O, N S , $\mathrm{NB})$ とし、入力変数は目標位置との誤差量 $\mathrm{E}$ と力制御方 向のマニピュレータ運動量 $M$ 。の 2 種類とする。ファジィ変 数は，式 (8) で表されるシグモイド関数と式 (10)で表され るガウシアン関数の両方を用いることにより単層のニュー ラルネットワークで前件部を構成するものとする。

$$
\begin{aligned}
& f_{S}\left(u_{S}\right)=\frac{1}{1+e^{-u_{S}}} \\
& u_{S}(x)=w_{o}+w_{i} x \\
& f_{G}\left(u_{G}\right)=e^{-u_{G}^{2}} \ldots \\
& u_{G}(x)=\frac{w_{0}+x}{w_{i}} \cdots
\end{aligned}
$$

ここで, $w_{o}$ はしきい值, $w_{i}$ はウエイト值である。ガウシアン 関数では，これらの值はそれぞれメンバーシップ関数の中 心値と偏差値を表す。

後件部は I F - T H E Nの制御ルールに従い，前件部適 合度の代数積に定数值をかけ合わせた各ルールからの出力 和を前件部適合度の和で割って定数值出力を得るものとす る。この制御器からの定数值出力が, 基準座標系でのマニ ピュレータへの力指令Uである。

FNN力制御器の学習は，次の評価関数が最小よなるよ うにバックプロパゲーション法を用いて前件部と後件部の 両方の微調整を各サンプリング毎に行うものとする。

$$
Y=\frac{1}{2}\left(f_{d}-f\right)^{2}
$$

各部でのウエイト值の変化量は次の通りである。

$$
\text { 後件部: } \Delta w_{r}=\eta\left(f_{d}-f\right) y_{b} y_{k}
$$




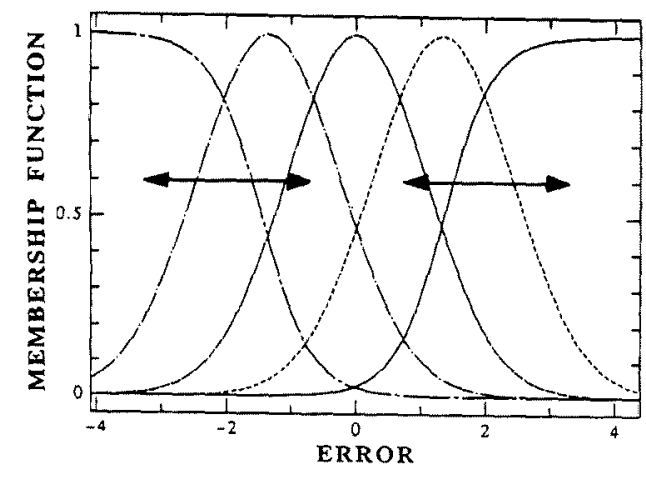

図 4 メンバーシップ関数の変化

Fig.4 Change of membership function

前件部： $\Delta w_{i}=\eta \Sigma \frac{\partial e_{i j}}{\partial y_{i j}} f_{(u)}^{\prime} u^{\prime}$

ここでクは学習係数, $f_{d}$ は目標力, $f$ は実際に測定された 力, $y_{i j}$ は前件部出力, $e_{i j}$ は前件部出力誤差, $f^{\prime}{ }_{(u)}$ 之 $u^{\prime}$ は式 (8)(10)で表されるアクティベーション関数とその人力の微 分である。

この学習により、設計したファジィ制御則が完全でなく ても，ロボットマニピュレータの関節の摩擦が完全に補償 されていなくても，また外乱が作用したり環境の動特性が 変化しても，目標通りの力を末知環境に加えることが可能 になる。

〈3・2〉 I ANN 本FNN力制御器により、ほとん どの場合オーバーシュートすることもなく目標通りの力を 制御できる。しかし，もし対象物の動特性が想定していたも のよりもかなり硬かった場合は大きなオーバーシューティ ングが発生する等の問題が生じる。しかし，もし未知環境に 力を与え始めた早い段階で, 環境の変位量とその変位によ り発生した力との関係から環境が想定していたものより硬 いか柔らかいかを判断し，それに応じて制御器の前件部を 調整すればそれらの問題を解決できる。そこで本稿では，F NN力制御器への入力情報である誤差とマニピュレータ運 動量の 2 つ両方を，環境の硬さに応じ調整するニューラル ネットワーク I ANNを提案する。

I ANNでF N N力制御器の入力值を瞬時に調整するこ とにより，設計時に定義されたメンバーシップ関数を環境 の硬さに応じ，横に広げたり狭めたりしたような形状に変 更するの上同じ効果が得られる (図 4 参照)。つまり制御器 の前件部の定義の変更が瞬時にできる。例えば，もし環境が 想定していたものよりも硬かった場合は，その硬さ加滅に より制御器への入力情報である目標力との愦差量を小さく, 力制御方向のマニピュレータの運動量を大きく変換してや ることにより，実際にはまだ詥差が大きい時点で浛差が小 さいときのようにきめ細かく制御され，環境を押す速度の 定義も変更できるようになる。

I A N Nへの入情報は，瑾境の変位，環境の変位速度， 環境の変位加速度そこして環境からの反力の4つとした。I

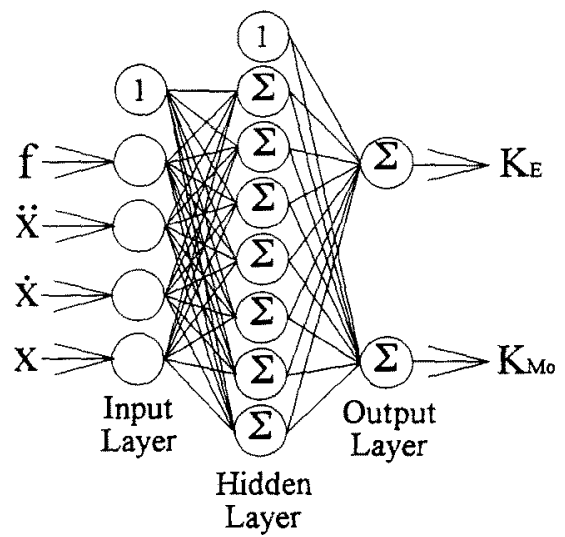

図 5 入力調整ニューラルネットワーク ( I A N N ) Fig.5 Input Adjusting Neural Network (IANN)

A N Nの隐れ層と出力層のアクティベーション関数は, シ グモイド関数を使うことにした。I A N Nからの出力は，F $\mathrm{N} \mathrm{N}$ 制御器の入力情報である䛊差量 $\mathrm{E}$ に対する調整係数 $\mathrm{KE}$ と力制御方向のマニピュレータ運動量 $M_{0}$ に対する調整係数 KMoの2つとした。I A N Nからの出力である2つの調整 係数は正の数とし，出力層にシグモイド関数を用いること により予め設定した上限と 0 の間で変化するものとした。 環境の動特性が設計時と同じだったら2つの調整係数は両 方とも1を出力するように学習させる。I A N Nの詳細を 図 5 に示す。

I ANNの学習は, オフラインでバックプロパゲーショ ン法により予め学習しておくものとした。教師信号として， 設計時に想定した環境のよりも硬いものと柔らかいものを 数パターン用意し，設計時に想定していたものより硬けれ ば硬いほど䛊差量調整係数KEを1より小さく，力制御方向 のマニピュレータ運動量調整係数 KMoを1より大きくなる ように学習させる。また，柔らかい場合にはその逆になるよ うに学習させる。このとき，具体的にどれ位の固さのときに どの程度調整係数を大小させるかは，ファジィ制御を設計 するのと同様に熟練者の知識や経験により決めるものとす る。例えば，設計時に想定した環境 $\mathrm{A}$ を扱う際のファジィ制

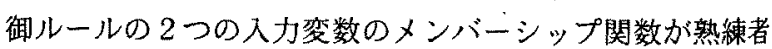
により図4のように定義されるとし，熟練者がそれより固 い環境 $\mathrm{B}$ を扱う際のファジィ制御ルールの入力変数 $\mathrm{E} の メ$ ンバーシッフ関数が，図4を横に1.5倍広げたような形で定 義され，もう一方の入力変数 $M$ 。のメンバーシップ関数は， 図 4 を横に0.7倍狭めたような形で定義されたよする。この とき環境 Bに力を加えたときの環境 Bの変位, 変位速度, 変 位加速度，そして反力の 4 情報が環境 Bについての学習パ ターンのインプットとなり，1.5と0.7の逆数がその入力に より発生すべき出力 $\mathrm{KE}, \mathrm{KMo}$ となる。ここで, 環境 $\mathrm{B} に つ$ いての学習パターンの目標出力は固定されるが, 入力につ いては無限の組み合わせがある。そこで, 入力パターンの組 み合わせとして環境 Bの変位, 変位速度, 変位加速度各々の 


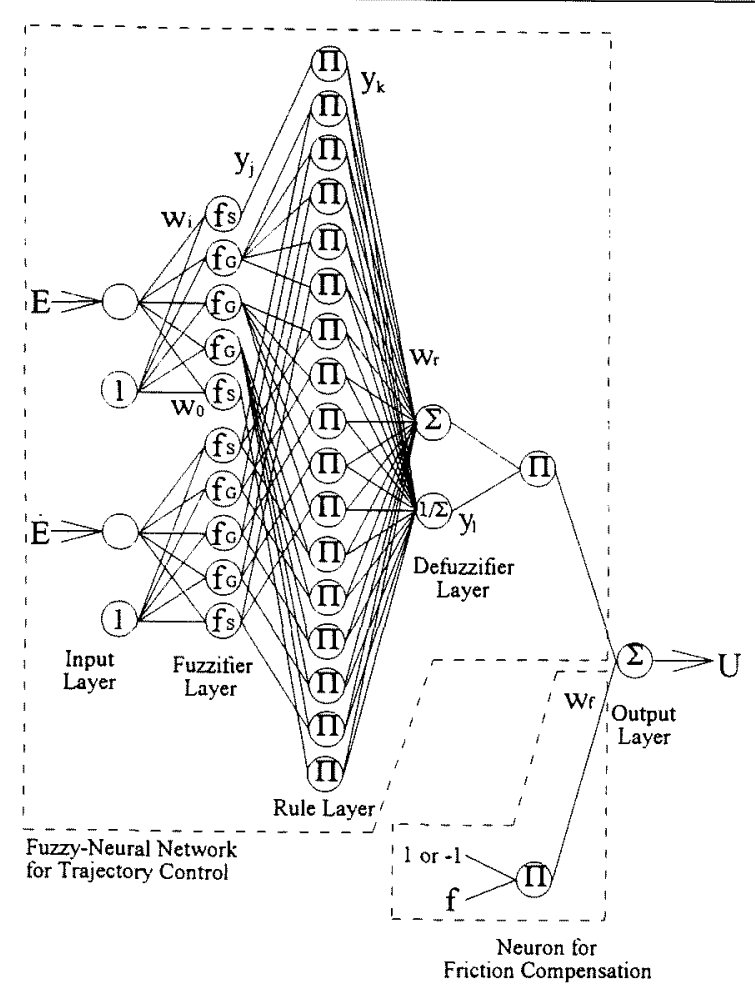

図6 ファジィ・ニューラルネットワーク位置制御器

Fig.6 Fuzzy Neural Controller for position control

実際に変化しうる範囲を数十一数百に分割し，その全ての 組み合わせについて学習させるものとする。このとき環境 からの反力は, 環境の変位, 変位速度, 変位加速度により決 まる。即ちオフラインでの I A N Nの学習は，固さの異なる 数パターンの環境に対し，その環境の変位，変位速度，変位 加速度とそれらにより発生する反力の各々を前述の組み合 わせで変化させることにより行うものとする。学習を効率 良く行うため，学習パターンの提示方法は，1つの環境に対 する学習を終えてから次の環境について学習を行うのでは なく，全ての環境に対する学習を交互に行うものとした。即 ち, 1 つの環境に対してその環境の変位, 変位速度, 変位加 速度及び環境からの反力の 1 入力パターンと，それに対す る出力パターンであるその環境の調整係数の 1 学習パター ンを提示して学習した後, 次にその環境に対する別の学習 パターンを提示するのではなく，別の環境に対して 1 学習 パターンを提示し学習させるものとする。

一方, I A N Nの沉化, 即ち未学習の学習に対しても適切 な値を出力できるかどうかは重要な問題である。本 I A N Nのような 3 層ニューラルネットワークにより非線形マッ プが構筑できることは既に証明されている ${ }^{(14)}$ 。しかし，汎 化能力や過学習 ${ }^{(15)}$ の問題については幾つかの方法 ${ }^{(16)}$ が発 表されているが, 未だ確立した評価法はない。一般的には学 習パターンが多ければ多いほど价化能力が向上されるので， 実用の際には実際に扱うであろう全ての材料に対して学習 しておくことが望まれる。

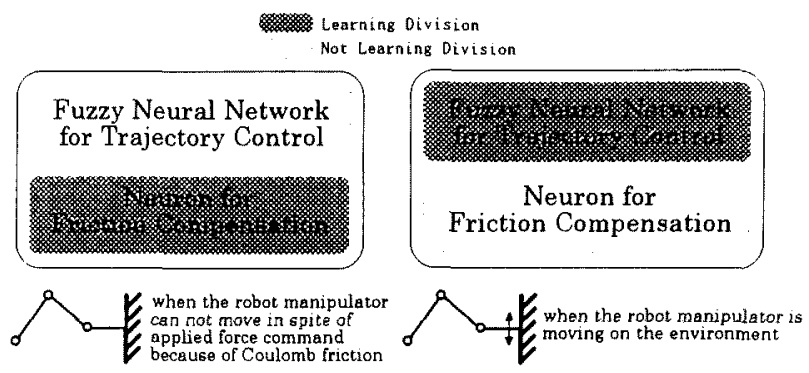

図7切り替え学習法

Fig.7 Switch-Learning Algorithm

\section{4.末知棵境上での位而制御}

環境に力を加えながら同時に位置を制御しようとする場 合，いかに環境とロボット間のクーロン摩擦の補償を行う かが問題となる。クーロン摩擦の大きさは次式で示すよう に動摩擦係数と環境表面に垂直に作用する力との積であり， 環境に加える力によっても変化するので補償するが難しい。

$$
F_{e r}=\mu_{k} f
$$

ここで, $F_{e r}$ はクーロン摩擦, $\mu_{k}$ は動摩擦係数, $f$ は環境表面 に垂直に作用する力である。

この章では，摩擦補償用二ューロンを持つファジィ・ ニューラルネットワーク位置制御器を利用して, 前章で説 明したF N N力制御器により環境に対し目標通りの力を加 えながら環境表面上でロボットマニピュレータの位置を制 御する際に効果的な摩擦補償方法を説明する。以降, ファ ジィ・ニューラルネットワーク位置制御器をF N N 位置制 御器と呼ぶことにする。F N N 位置制御器は, ロボットマニ ピュレータの軌道を制御する軌道制御用ファジィ・ニュー ラルネットワーク部と，環境とロボット間の摩擦補償を行 う摩擦補償用ニューロン部の 2 つで構成されている。本稿 で提案するF N N位置制御器の詳細を図 6 に示す。この位 置制御器の $2 つ$ 部は, 同時に学習することはなく, 状況に より学習の切り換えを行うこととした。即ち, 位置制御のた めの力が加えられているにも関わらず，ロボットマニピュ レータが環境表面上で動かれない場合に摩摖補償用ニュー ロン部が学習し、ロボットマニピュレータが運動している 場合は軌道制御用ファジィ・ニューラルネットワーク部が 学習するものとする。この様子を図 7 に示す。

〈4・1〉仇道制御用ファジィ・ニューラルネットワーク

軌道制御用ファジィ・ニューラルネットワーク部では, 入 力情報として目標位置との愦差量とその変化量を用い、目 標軌道通りに運動するために必要なマニピュレータへの基 準座標系での力指令Uを出力する。入力情報として目標位 置との誤差量とその変化量を用いることと，学習のための 評洒関数が次式で表される位置誤差の 2 乗関数であること 以外は，構成及び学習方法共にく3・1>章で説明したF N N 力制御器と同じであるのでここでの説明は省略する。 


$$
Y=\frac{1}{2}\left(x_{d}-x\right)^{2}
$$

ここで, $x_{d}$ は目標位置, $x$ は実際に測定された位置である。 ただし，軌道制御用ファジィ・ニューラルネットワーク部 は，ロボットマニピュレータのエンドエフェクタ先端が運 動しているときのみ学習を行い, エンドエフェクタが動い ていないときは学習しない（学習係数が0となる）。

この軌道制御用ファジィ・ニューラルネットワーク部の 学習により，たとえ外乱が多少作用しても或いは摩擦補償 が完全でなくて屯，目標通りの位置へ移動させることが可 能となる。

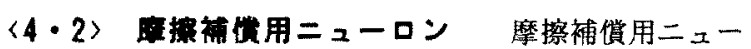
ロンは，環境に加えられている力 $f$ 之摩擦補償が必要な方 向（1或いはー1）上を入力情報とし，その入力を掛け合わ せた值にウエイト值Wfを掛けたものを摩擦補償力として出 力する。したがって, ある程度学習した後の摩摖補償用 ニューロンのウエイト值は, 環境とロボットマニピュレー 夕間の摩擦係数とほぼ同じ大きさになる。この出力と軌道 制御用ファジィ・ニューラルネットワーク部からの出力と を合わせたものが F N N位置制御器からの出力となる。

この摩擦補償用ニューロン部は，位置制御するための力 が与えられていにも関わらずロボットマニピュレータのエ ンドエフェクタが動かない場合のみバックプロパゲーショ ン法により学習するものとし、ロボットマニピュレータが 運動しているときは軌道制御用ファジィ・ニューラルネッ トワーク部が学習するものとする。従って，ロボットマニ ピュレータが運動し始めた後, 学習が軌道制御用ファジィ・ ニューラルネットワークに切り替わったら，摩擦補谈用 ニューロンはそれまでに学習した摩摖係数に従った摩擦補 償力を出力し続け，ロボットマニピュレータの運動方向が 反転したら摩擦補償用二ューロン八の入力の正負も反転す るので，運動の方向に関わらず摩擦補償を行うことができ る。

摩擦補儧用ニューロン部の学習のための評価関数は, 軌 道制御用ファジィ・ニューラルネットワーク部之同様で, 式 (16) で示したような位置愦差の2 萧関数である。摩擦補償 が必要な方向が 1 の場合のウエイト值の変化量は,

$$
\Delta w_{f}=\eta\left(x_{d}-x\right) f
$$

であり，摩擦補娧が必要な方向がー 1 の場合のウエイト值 の変化量は,

$$
\Delta w_{f}=-\eta\left(x_{d}-x\right) f
$$

となる。

摩擦補償用二ューロン部が学習しているときは，軌道制 御用ファジィニューラルネットワーク部は学習しないが ファジィ制御器として設計された通りの出力はするので, ここで学習した摩擦係数は実際の摩擦係数よりも小さな值 になる。しかし，摩擦補償の過不足は軌道制御用ファジィ・ ニューラルネットワーク部の学習により補償される。

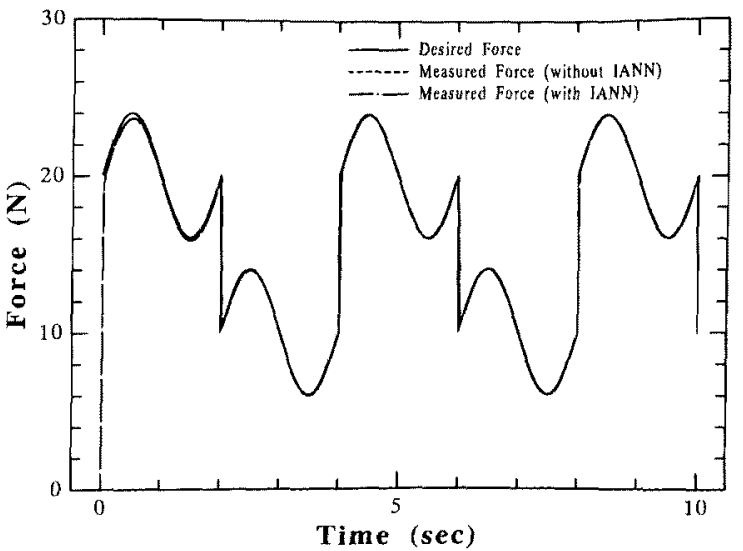

図 8 力制御シミュレーション結果 1

(環境の動特性が制御器設計時に想定したものと同じ場合)

Fig. 8 Force Control Simulation Result 1

(The environment is same as the model used for controller design)

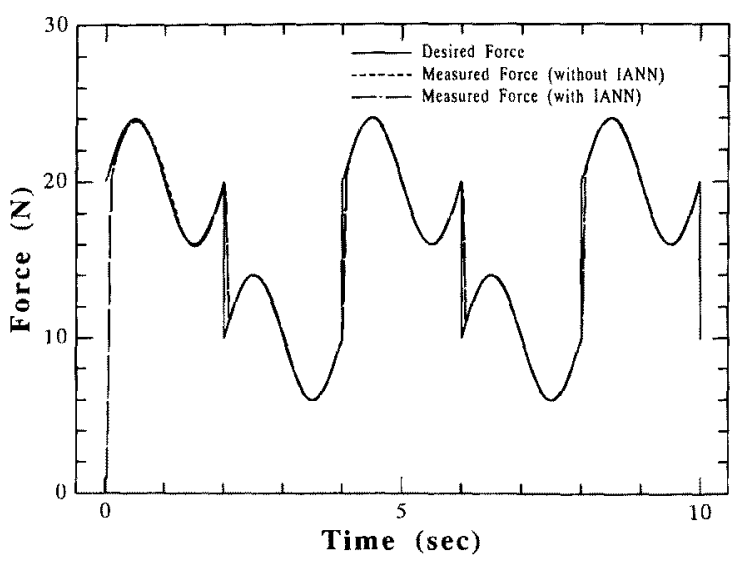

図 9 力制御シミュレーション結果 2

(環境が制御器設計時に想定したものよりも柔らかい場合)

Fig.9 Force Control Simulation Result 2

(The environment is softer than the model used for controller design)

\section{5. シミュレーション}

提案したハイブリッド制御器を評洒するため, 図1に示 したモデルを使いコンピューターシミュレーションを行っ た。位置/力制御の際のロボットマニピュレータのエンド エフェクタの角度は，環境に対し常に直角となるように加 速度分解制御を用いて制御した。シミュレーションでのサ

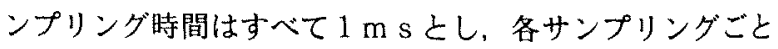
に位置ノ力制御器が学習するものとする。また、シミュレー ションでの環境は次式のようにモデル化した。

$$
f=M_{e} \ddot{x}_{e}+B_{e} \dot{x}_{e}+K_{e} x_{c}
$$

ここで, $x_{2}$ は環境表面の変位である。

IANNのオフライン学習には，制御ルール設計時に用 いた標準環境モデルの他, 式 (19) に示した各係数值を標準 環境モテルの $1 / 10$ 倍に変えた柔らかい環境モデル 1 種類， 


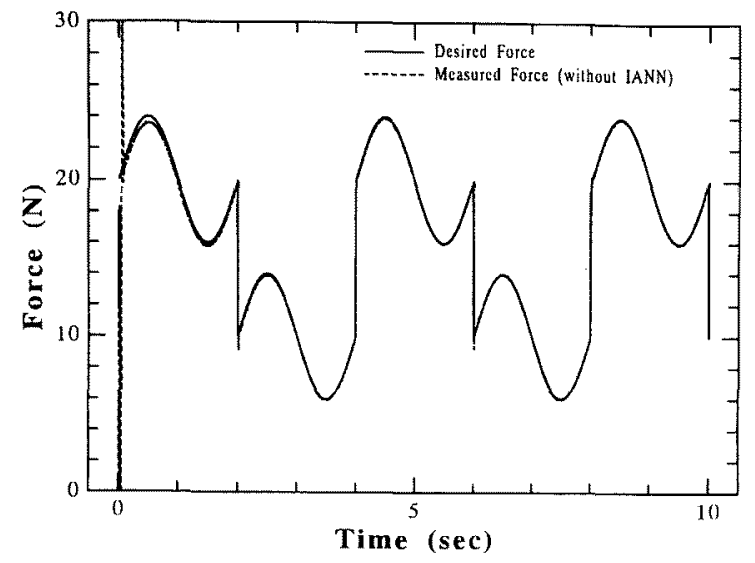

図 10 力制御シミュレーション結果 3

（環境が制御器設計時に想定したものよりも硬い場合 - I ANN無し)

Fig.10 Force Control Simulation Result 3

(The environment is harder than the model used for controller design - without IANN)

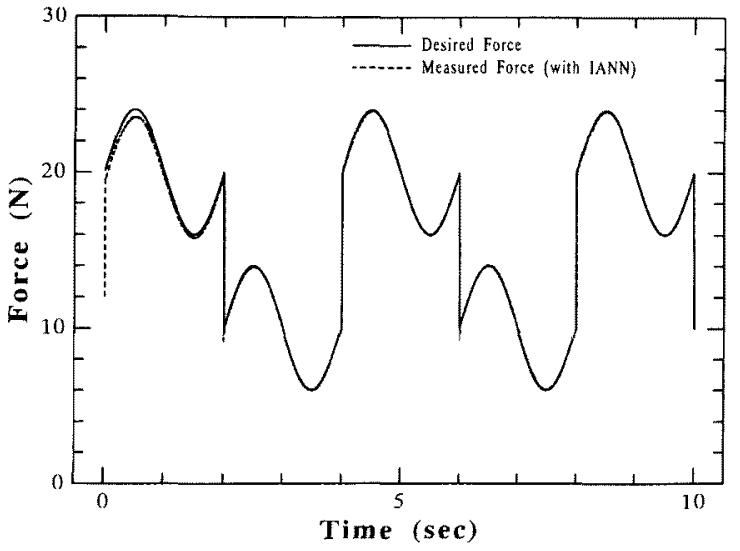

図 11 力制御シミュレーション結果 4

(環境が制御器設計時に想定したものよりも硬い場合 - I A N N有り)

Fig.11 Force Control Simulation Result 4 (the environment is harder than the model used for controller design - with IANN)

各係数値を5倍に変えた固い環境モテルと 10 倍に変えた固 い環境モデルの 2 種類, 合計 4 種類について，環境の変位， 恣位速度, 変位加速度を各々 $20,100,25$ パターンで变化さ せ，その各パターンと式 (19) により計算したそのパターン での反力を人力パターンとして用いた。また，各環境に対し I A N Cで出力する調整係数 KE とKMoは，標準㻴境のとき は各々 1 とし，各係数 $1 / 10$ 倍の環境モデルのときは 1.2 と 0.7 , 各係数 5 倍の環境モデルのときは $0.9 と 1.05$ ，各係数 10 倍モテルのときは 0.7 と 1.1 を各々の目標出力パターンとし てオフライン学習を行った。

最初に，提案した力制御器の有効性を評洒するためいく つかの動特性の異なる環境でのシミュレーションを行った。

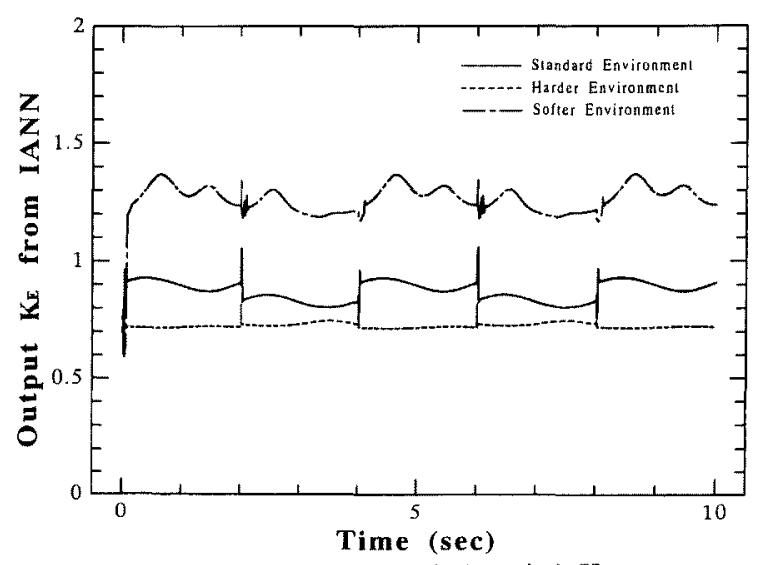

図12 I A N からの出力 $\mathrm{KE}$

Fig.12 Output from IANN : KE

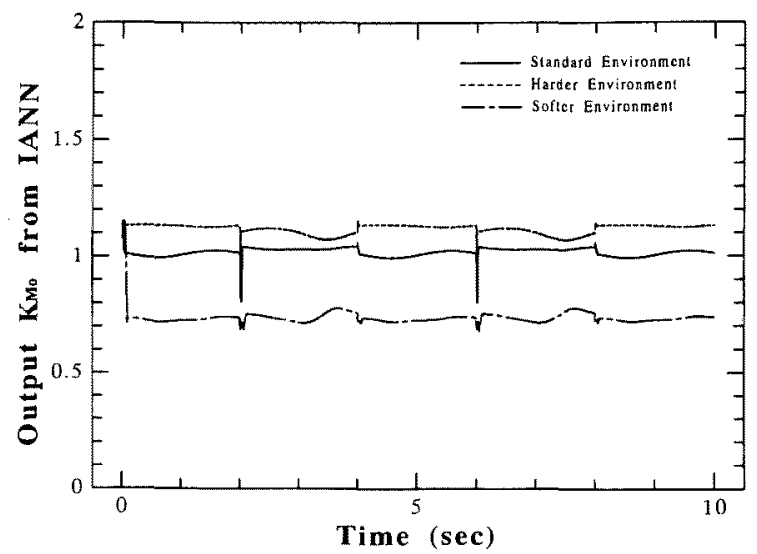

図 13 I A N Nからの出力KMo

Fig.13 Output from IANN : KMo

環境に加える目標力は 2 秒毎に $20 \mathrm{~N}$ と $10 \mathrm{~N}$ の間で変化 するステップ信号と $4 \sin (\pi \mathrm{t}) \mathrm{N} て ゙$ 表される曲線を組み合 わせたものとした。提案したI A N Nの效果を確かるため, I A N Nを付けた場合と付けなかった場合の結果を比較し た。まず、環境の動特性が制御器設計時に想定したモデルと 同じもののときのシミュレーション結果を図 8 に示す。こ の結果より，環境の動特性が設計時に想定していたもの之 同じだった場合は，IANNが有っても無くても結果は同 じで，環境に対し目標通りの力を加えることができること が確認できる。

次に式 (19)に示した環境モデルの各係数を制御器設計時 に用いた值の $1 / 10$ 倍に変えた争らかい環境に対してのシ ミュレーションを行った。このときの結果を図 9 に示す。こ の結果より，柔らかい唖境に対してもI ANNが有っても 無くても同じような良好な結果が得られるが, 制御器の学 習がまだ充分ではない最初の約 2 秒間は，若干ではあるが I A N Nが有るほうが良い結果を示した。

式(19)の環境モデルの各係数を制御器設計時の值の10倍 に変えたときは，IA N Nを用いなかった場合, 図 10 に示 すように初期の段階で大きなオーバーシュートが発生し振 


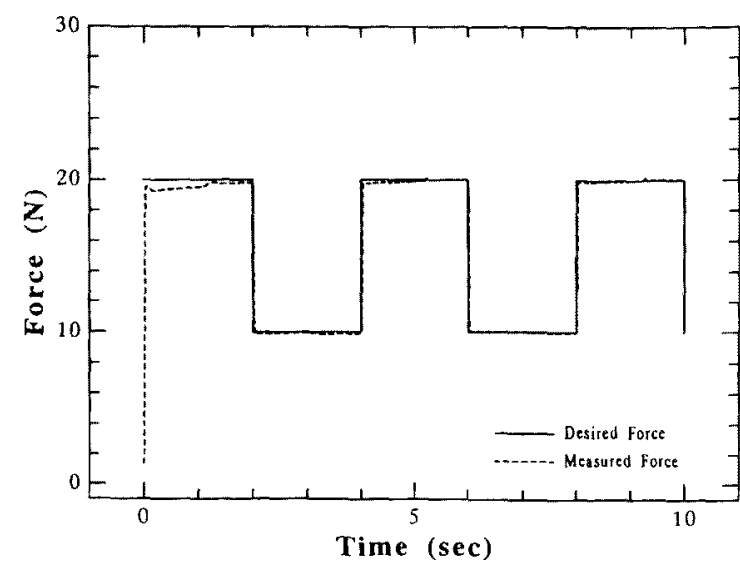

図 14 ハイブリッド制御の際の器境からの反力

Fig.14 Force response from the environment in the case of hybrid control

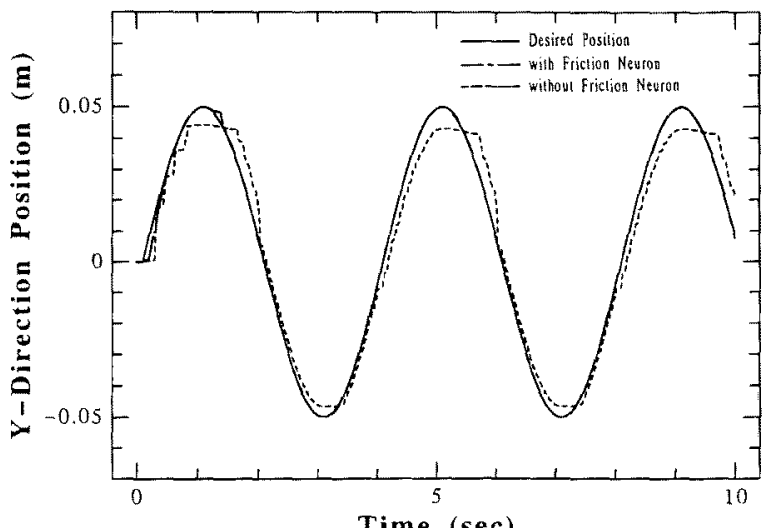

図 15 位置制御シミュレーション結果

Fig.15 Position control simulation results

動してしまう。これに対しIANNを用いた場合は，環境の 変位量とその変位により発生した力との関係から入力值を 瞬時に調整することにより，図１１に示すように非常に良 好な結果が得られることが確認できた。

これらのシミュレーションにおいてIA N Nが各環境モ デルに対して出力した調整係数 KE，KMoを各々図 12 上図 13 に示す。これらの出力結果より,オフライン学習により I A N Nがほぼ設定通りの值を出力できるようになってい ることが確諗できる。

次に，提案した位置制御器の有效性を評価するたる，未知 環境に対し図 14 に示すような2秒每に $20 \mathrm{~N}$ と $10 \mathrm{~N}$ 間 でステップ状に変化する力を加えながら，環境表面上を目 標位置 (目標軌道) $0.05 \sin (0.5 \pi \mathrm{t}) \mathrm{m}$ で追従するシミュ レーションを行った。このときの環境の動特性は制御器設 計時と同じものにした。

摩擦補償用二ューロンの效果を見るため，各シミュレー ションは摩擦補償用ニューロンを用いたときと用いなかっ たときの雨方の場合について行った。摩擦補償用二ューロ ンを用いなかったときは，本稿で提案した位置制御器の軌
道制御用ファジィ・ニューラルネットワーク部のみでの制 御之なる。この場合は, 学習の切り替えは行わず最初から軌 道制御用ファジィ・ニューラルネットワーク部が学習する ものよする。シミュレーションでの環境とロボット間の クーロン摩擦係数は，摩擦補償用二ューロンの効果を評湖 するため，かなり大きめの 4.0 に設定した。このときのシ ミュレーション結果を図 15 に示す。この結果より,摩擦補 償用ニューロンを用いた場合には的 0.3 秒で目標軌道通り 運動し始めるのに対し, 用いなかった場合には 3 周期目 (1 周期は 4 秒)になってもまだ目標軌道通り運動していない のがわかる。また，摩擦補償用二ューロンを用いなかった場 合は，2秒每に変化する環境からの反力の大きさに影響さ れているの対し，用いた場合には影響を受けていないのが 確認できる。

\section{6. まとめ}

ニューラルネットワーク及びファジィ・ニューラルネッ トワークを利用して未知環境に対し位置と力を同時に制御 するハイブリッド制御法を提案した。本制御器を用いるこ とにより，動特性の末知な環境に対し目標通り力制御でき ることを示した。ただし，今回本稿でI A N Nの学習に用い た教師データは架空の值なので，今後教師データとして実 際の材料の動特性データを使うことが望ましい。

また本稿では，力を加えながらの位置制御において，環境 とロボット間の摩擦力の補償量が未知であっても，摩擦補 償用ニューロンを用いることにより有效に摩擦補儥を行う 方法を提案すると共に，状況により学習を切り替える切り 替え学習も提案した。本位置/力制御器の有効性は平面 3 自由度ロボットマニピュレータのモデル使用しコン ピューターシミュレーションにより確認した。

(平成 7 年 10 月 25 日受付, 同 8 年 3 月 21 日再受付)

\section{文献}

(1) M.H.Raibert \& J.J.Craig : "Hybrid position/force Control of Manipulators," Trans. ASME Journal of Dynamic Systems, Measurement, and Control, 102, 126 133 (1981)

(2) N.Hogan : "Impedance control : An approach to manipulation : Part I - Theory; Part II - Implementation; Part III - Applications", ASME Journal of Dynamic Systems, Measurement, and Control, 107, 1 24 (1985)

(3) Z.Lu \& A.A.Goldenberg : "Robot Impedance Control and Force Regulation : Theory and Experiments," The Int. J. of Robotics Research, 14-3, 225 254 (1995)

(4) Z.Peng \& N.Adachi : "Position and Force Control of Manipulators without Using Force Sensors", JSME Int. J, Ser.III, 35-2, 252 258 (1992)

(5) E.H.Mamdani : "Application of fuzzy algorithms for control of simple dynamical plants", Proc. of IEE, 121 
$1585 \sim 1588$ (1974)

(6) 菅野: ファジィ制御（昭63）日刊工業新聞社

（7）下島・福田・新井：「R B F 型ファジィ推論とその応 用」, 第 11 回日本ロボット学会学術講演会予稿集, 131 132 (平 5)

( 8 ) T.Yabuta \& T.Yamada : "Possibility of Neural Networks Controller for Robot Manipulators", Proc. of IEEE Int. Conf. on Robotics and Automation, 1686 1691 (1990)

(9) T.Fukuda \& T.Shibata : "Neural Network Application for Robotic Motion Control", Journal of Robotics and Mechatronics, 2-3, 21 25 (1991)

(10) 柴田・福田・小菅・新井・铇田・光岡 :「神経回路モデ ルによるロボットマニピュレータの位置・力制御(第 6 報)」, 機論, 58-549, C 1442〜 1449 (平 4)

(11）木口・D.S.Necsulescu・福田：「ニューラルネットワー クを利用した未知環境でのハイブリッド制御」, 日本 ロボット学会誌, 13-2 131〜136 (平 7-3)

(12) K.Kiguchi \& T.Fukuda : "Robot Manipulator Contact Force Control Application of Fuzzy-Neural Network", Proc. of IEEE Int. Conf. on Robotics and Automation, vol.1, 875 880 (1995)

(13) 木口・福田：「ファジィ・ニューラルネットワークを 利用した複腕ロボットによる未知対象物の制御」, 機 論, 61-589，C，3643 3649 (平 7-9)

(14) K.Funahashi : "On the Approximate Realization of Continuous Mappings by Neural Networks", Neural Networks, vol.2, 183 192 (1989)

（15）小川・山崎：「過学習の理論」, 信学論 D-II, vol.J76-DII, no.6, 1280 1288 (平 5 )

(16) G.Deco, W.Finnoff \& H.G.Zimmermann : "Unsupervized Mutual Information Criterion for Elimination of Overtraining in Supervized Multilayer Networks", Neural Computation, vol.7, no.1, 86 107 (1995)

木口 量夫（非会員）1964 年 2 月 15 日生まれ。1986 年

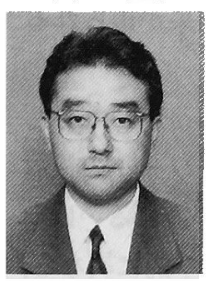
新潟大学工学部機械工学科卒業。マツダ株 式会社等の勤務を経て，1993 年カナダ University of Ottawa 大学院博士前期課程修 了。現在新潟工業短期大学生産システム工 学科講師。ロボットのニューロ・ファジィ制 御, 知能ロボットの研究等に従事。

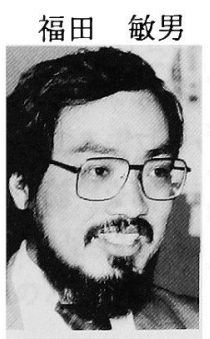

（正員）1948年 12 月 12 日生まれ。1971年早 稲田大学理工学部機械工学科卒業。1977 年 東京大学大学院博士課程修了。工博。通産省 工業技術院機械技術研究所研究官, 東京理 科大学工学部機械工学科助教授を経て, 1989 年 4 月より名古屋大学工学部機械情報 システム工学科及びマイクロシステム工学

電学論 $C, 116$ 巻 7 号, 平成 8 年
科教授。IEEE IES Vice President, IEEE NNC Secretary, IEEE R\&A TC 委員長等歷任。 